\title{
NATO, Russia and European Security: Lessons Learned from Conflicts in Kosovo and Libya
}

\author{
Philip Spassov *
}

\begin{abstract}
The essay analyses the role of NATO in the post-Cold War period by conducting a comparison of the cases of NATO's operations in Kosovo and Libya. The article reveals the enhanced weight of the Alliance member states and the European countries' active role in protecting their regional interests and also show how the state interests of the USA and Russia played a significant role in the two cases. This analysis of the behavioral patterns of the former Cold War adversaries could provide a useful interpretation and perhaps an explanation of the current events in Ukraine. The pursuit of power continues to dominate the international relations arena as the confrontation between the USA and Russia is far from over.
\end{abstract}

Keywords: European security, power politics, geopolitical influence, national interest.

\section{Introduction}

European security has a rich history of violent and destructive conflicts. It has gone through countless state-to-state wars, two World Wars, the ideological confrontation of the two superpowers during the Cold War period, and the new threats of terrorism and ethnic violence in the modern era. In the twenty-first century, Europeans face a number of new security challenges, such as regional conflicts and genocide, terrorism, economic, technological and energy issues, all of which affect European security.

With the end of the Cold War, NATO experienced a major transformation. The Alliance's decision-makers acknowledged that, with the disappearance of the Soviet Union, new threats had emerged. It was essential for European security that NATO should develop a strategy for tackling future security threats. This strategy engaged NATO in numerous assignments that would ensure the protection of western-projected democracy.

In other words, NATO remains the main factor for European and regional security. The Alliance's recent missions and expansion could lead the organization even to a global role in the future. NATO stands as a pillar of European security and defends western values and interests.

As international security is the most important global issue there are several political theories that emphasize the importance of providing better comprehension. The understanding of global security matters has been best explained by the international relations

\footnotetext{
Philip Spassov currently works as a chief expert in the Capabilities Branch of the Crisis Management and Disaster Response Centre of Excellence (CMDR COE), located in Sofia, Bulgaria. He holds a BA in International Relations from Southwestern University in Blagoevgrad (2011) and a master degree in Global Political Studies from Malmo University, Sweden (2012).
} 
theory of realism. ${ }^{1}$ According to this theory, which has long dominated the study of international relations:

Despite the end of the cold war, the basic structure of the international system remains largely unchanged. States are still the key actors in world politics, and they continue to operate in an anarchic system. ${ }^{2}$

Its explanations of security competition among great powers remain applicable and provide a logical explanation to the events in the international arena nowadays. The traditional security focus on nation-states and power remain central for international relations regardless of all the changes in the global order in the last 60 years. ${ }^{3}$ Despite being strongly criticized after the end of the Cold War, realism should not be underestimated or neglected for international relations. Realism can offer a lot to political analysts because the major powers will continue to compete for supremacy and wars will continue to occur.

This essay analyzes the role of NATO in the post-Cold War period and the importance of how powerful states' interests are concerned, mainly the USA and Russia. Within this framework, the cases of the Kosovo crisis and the Libya uprising will be compared. European security was threatened in similar ways during these two conflicts. Although violations of human rights and crimes against humanity were the official reasons for the military interventions of NATO, the present article will also show how these conflicts affected the interests of the major NATO members and of Russia.

It will be argued that state interests and competition between the major powers in the global arena remained essential and that the USA and Russia took similar approaches to resolve the European security crisis without disregarding their national interests.

The comparative case study method is used here, since it is not limited in terms of descriptive or explanatory goals and, therefore, it is useful for a deeper analysis using the similarities or differences of the cases. Comparative case studies are particularly useful for the study of change over time. The review of the cases over a given period of time will show a specific trend and whether this has changed.

Furthermore, the operations in both cases would be used for examining the new purposes and goals of NATO and whether the organization has become more efficient and capable in the period between the two wars.

In order to illustrate the behavior of the USA and its Allies and Russia, the realism theory will be used, since its relevance in international politics has not waned. On the contrary, its basic ideas still remain essential nowadays. According to realist logic, the state remains the main actor in contemporary international relations. States control most of the planet's military power and resources and they issue world currencies. International organizations are formed by states and they are governed by states. They depend

1 Sean Kay, Global Security in the Twenty-First Century: The Quest for Power and the Search for Peace (Lanham, MD: Rowman \& Littlefield, 2012), 16.

2 John J. Mearsheimer, Realism, the Real World, and the Academy, in Millennial Reflections on International Studies (Ann Arbor, MI: The University of Michigan Press, 2002), 26.

3 Ibid., 2. 
on the military power and economic support of the states as well as on state's territory on which they operate. Therefore, from a realistic perspective, international organizations could be successful only if they are backed by powerful states. ${ }^{4}$

States are still considered the main actors and they assess their security needs in terms of power. ${ }^{5}$ Security competition evolved from traditional military armament to researching advanced technologies, competition for markets and strategic resources. This competition is likely to continue, as great powers will pursue economic gains and power distribution to achieve a dominant position within the global system. ${ }^{6}$

The new threats in international relations in the twenty-first century, namely terrorism, global warming, overpopulation and regional conflicts, no matter how serious and how difficult to resolve, do not pose a sufficient threat for the existence of any of the major states. ${ }^{7}$ However, they pose an exceptional threat to human security, development and human rights.

International organizations are dependent on the self-interest of great powers and have little impact on state behavior. ${ }^{8}$ This means that international organizations are interpreted as tools in the power competition between the most advanced countries and for achieving their national interests. Especially when it comes to security issues, realism theory explains international politics in a clear and simplified way. States aim to maximize their power and influence over the other states. Every state competes with others, aiming to acquire more power and influence over them, because this is the best way to ensure its future. The best outcome for a state's survival is to end up as the hegemon in the system. ${ }^{9}$ This would lead to maximizing the power of one state at the expense of the other major powers. The United States and NATO represent a significant example of this.

\section{Background of the Conflicts: Kosovo}

Kosovo is located in the southwestern part of the Balkan Peninsula. The region was part of Serbia within former Yugoslavia. It is inhabited mainly by ethnic Albanians and its territory has been disputed between Serbs and Albanians for generations. Before 1989 Kosovo enjoyed a relatively high degree of autonomy in Yugoslavia, but with the election of Slobodan Milošević things rapidly changed. Kosovo's autonomy ceased as the territory was put under the direct command of Belgrade. This led to organized protests of thousands of Albanians demanding more civil rights and freedom. Albanians and Serbs in Kosovo were isolated and separated. This increased the number of protesters demanding autonomy and independent governance. More that 400000 Kosovo Albani-

4 J. Samuel Barkin, International Organization: Theories and Institutions (New York: Palgrave Macmillan, 2005), 8.

5 Kay, Global Security in the Twenty-First Century, 33.

Ibid., 34.

Ibid., 36.

Ibid., 331.

Ibid., 337. 
ans fled because of the oppression and the rapidly deteriorating socio-economic conditions. Passive opposition and peaceful protests were soon replaced by violence as nationalistic movements in Kosovo spurred further tension. The situation became very unstable and escalated into armed clashes between Albanian and Serbian military and police forces. $^{10}$

The international community condemned the escalation and called for an immediate ceasefire and withdrawal of Serbian forces, fearing that the conflict could spread to other regions in the Balkans. The UN Security Council adopted resolution 1199 in September 1998 condemning "all acts of violence by any party, as well as terrorism in pursuit of political goals." 11 It was later followed by another resolution (1203 from October 1998) calling for immediate ceasefire and the establishing of an observer mission of the Organization for Security and Cooperation in Europe (OSCE). ${ }^{12}$

Despite these measures, the situation intensified in 1999 and numerous clashes occurred. The presence of OSCE observers prevented some incidents but the situation deteriorated further. Diplomatic talks ground to a halt and Serb forces increased their military presence in Kosovo. The USA issued an ultimatum to Milošević but he did not comply with it and on 23 March NATO's Operation Allied Force commenced. It lasted for seventy-seven days and ended on 10 June 1999.

The results of the clashes between Serb military forces and Kosovo Albanians were reportedly around 3,400 missing and a total of more than 13,000 killed (mainly Albanians), according to a document published by the International Committee of the Red Cross. ${ }^{13}$ By November 1999, around eight hundred thousand refugees had returned to their homes. ${ }^{14}$

\section{Background of the Conflicts: Libya}

Libya is located in the northern part of the African continent and was ruled by Colonel Muammar Al-Qaddafi for more that four decades. He came into power after a coup against King Idris and his willingness to kill civilians that threaten his position was well known to the international community. His leadership of the country, which included banning political parties and sponsoring terrorism, was always controversial. Also, Colonel Qaddafi was often accused of siphoning off much of the profits from oil exports, the main source of revenue for the country, for himself and his family. ${ }^{15}$

The recent events in Libya were part of the Arab Spring processes that spurred over the North African states in 2011. Following the democratic changes in Egypt and Tuni-

${ }^{10}$ Historical Overview NATO's role in relation to the conflict in Kosovo, NATO official statement, 15 July 1999.

11 UN Security Council Resolution 1199 (1998).

12 UN Security Council Resolution 1203 (1998).

13 Ministry of Foreign Affairs, Yugoslavia, "Provisional Assessment of Civilian Casualties and Destruction in the Territory of the FRY from 24 March to 8 June 1999" (8 June 1999), 24-26.

14 US State Department Report, December 1999.

15 Anup Shah, "Crisis in Libya," Global Issues (April 2011), 2. 
sia, the people of Libya likewise wished to turn their back to the oppressive regime of Muammar Al-Qaddafi. However, their hopes for a peaceful transition of power did not come true. Qaddafi's dictatorial regime reacted to the protests with the use of violence, threatening to kill all dissidents. The situation continued to escalate and the clashes between Qaddafi's forces and protesters became a serious threat to both human rights and the stability of the region. Thousands of refugees fled to neighboring countries as their lives were in danger. The UN reacted quickly and imposed an arms embargo and a nofly zone, banning all flights over Libyan airspace except those for humanitarian aid purposes. ${ }^{16} \mathrm{UN}$ resolution 1973 condemned the human rights violations, torture and executions, and allowed an intervention by the international community. NATO responded and on 22 March started Operation Unified Protector. The operation aimed to protect the civilian population of Libya by enforcing the arms embargo and no-fly zone. Throughout the conflict, the Alliance was in close contact with the UN, the Arab League and other international partners. This essentially contributed to the efficiency and success of the operation. Furthermore, NATO helped to overthrow Qaddafi's regime by conducting air strikes against military forces that were threatening protesters in areas populated by civilians. ${ }^{17}$ The operation ended on 21 October 2011, a day after the opposition captured and executed Qaddafi. The casualties of the conflict were estimated to be around 20,000 with many more wounded or chased away from their homes. ${ }^{18}$

\section{NATO's Role Reviewed}

The North Atlantic Treaty Organization is a military institution the role of which has changed over its more than sixty years of history. In the twenty-first century, when the United States is the sole dominant superpower, NATO is seen as a hegemonic tool for the pursuit of American national interests. ${ }^{19}$ The military operations in Iraq, Kosovo, Afghanistan and Libya gained strategic influence and accumulated assets for the USA and, in smaller part, for the western European allies. It is no secret that all the aforementioned states, except Kosovo, possess significant reserves of oil and natural gas.

Furthermore, one could argue that NATO's security policy in Europe consists in serving Washington's interests in order to constrain Germany and Russia as security competitors. ${ }^{20}$ The Unites States' interests in Europe are essential in order to maintain its world supremacy. Establishing a strong military presence and eastward enlargement are also steps towards limiting Russia's strategic positions in Europe. As Kenneth Waltz noted, "The effort to maintain dominance stimulates some countries to work to over-

16 NATO official report on Libya, May 2011.

17 NATO official report on Libya, May 2011.

18 Paul Rogers, The Casualties of War: Libya and Beyond, Oxford Research Group, 7 July 2011, available at www.opendemocracy.net/paul-rogers/casualties-of-war-libya-and-beyond (13 May 2014).

19 Alexandra Gheciu, NATO in the New Europe: The Politics of International Socialization after the Cold War (Redwood City, CA: Stanford University Press, 2005), 214.

20

Kay, Global Security in the Twenty-First Century, 41. 
come it." 21 And yet, no one has challenged America's dominance and NATO's role in the post-Cold War era.

NATO's dialogue with Ukraine, Georgia and the Mediterranean countries further extends its transatlantic influence and disturbs Russian interests. This hegemony of the United States has a positive influence over the new members and the strategic partners of NATO. By promoting western values and democratic norms, it has opened a door for economic cooperation and thus accelerated states' development. Security aside, this is one of the main reasons why many of the former Soviet allies declared their desire to join the Alliance.

The Alliance has offered partnerships for peace and consultations to all former Warsaw Treaty members and conducted talks with Mediterranean and Middle Eastern states for possible future cooperation. ${ }^{22}$ The North-Atlantic Treaty Organization has been preserved and transformed in such a way as to tackle new issues and threats in the aftermath of the Cold War era. Former secretary general Jaap de Hoop Scheffer stated that the Alliance share common visions and ideas:

Europe and North America can disagree, sometimes quite strongly, but they remain the world's closest community - not only in trade or shared security interests, but also in common values. $^{23}$

NATO is still an important player in international affairs because the USA maintains its interest to keep the organization intact. NATO also serves the interests of its European members as it allows them to focus on development and cooperation, as well as on resolving national matters. Although many researchers consider NATO's existence to be unnecessary in the post-Cold War period, we can only speculate what consequences its dismantling would have. The United States maintain its strategic influence in Europe and in the Mediterranean and use NATO to preserve its national interests as a superpower. On the other hand, European allies require US military support in order to feel safe and protected from any threats, including one from among themselves. Thus, European states can implement their beautiful project for a united Europe. Moreover, America and the EU share a common vision of NATO's existence and expansion. NATO serves the interests of its members by protecting their shared traditions and western values. $^{24}$

NATO's military operations, no matter how criticized they might have been, provide stability and guarantee security across the continent. The shared vision of its members and the effective methods for tackling new security threats show that NATO will be an important part of the international security in the future.

21 Kenneth N. Waltz, "Structural Realism after the Cold War," International Security 25 (Summer 2000), 37.

22 Sten Rynning, NATO Renewed: The Power and Purpose of Transatlantic Cooperation (New York: Palgrave Macmillan, 2005), 1.

23 Ibid., 3.

24 Rynning, NATO Renewed, 4. 


\section{The Crisis in Yugoslavia: Kosovo War and NATO's Intervention}

NATO remains the main provider of security in Europe in the post-Cold War period. One of the most notable examples of its changed role was the operation undertaken against the Serbian authorities in the Kosovo War in 1999. NATO went to war for the first time in its history against the leadership of Slobodan Milošević. ${ }^{25}$ The ethnic crisis in Kosovo was a considerable challenge for the Alliance. Human rights violations and atrocities against the Albanian population in the Kosovo region had put Europe on the brink of disaster. For the European members of NATO and their respective governments the stakes were extremely high as a result of the high expectations from their own voters. Moreover, NATO's existence and, more importantly, NATO's purpose, had been questioned since the end of the Cold War. Therefore, the organization had to respond to the crisis in Yugoslavia.

After the escalation of the conflict, US and European leaders condemned the violence and implemented measures to restore international peace and security. Although legitimized by humanitarian reasons, an intervention did not receive UN approval because of the vetoes of Russia and China. ${ }^{26}$ Despite this, NATO started air strikes against Serbian authorities on 24 March 1999. Russia strongly criticized the operation because it bypassed the UN Security Council and it was a violation of both international law and Serbia's sovereignty, since Kosovo was part of its borders. ${ }^{27}$ The military actions of NATO and the US government concerned the other major powers in the world, most notably Russia. On the other hand, "[m]any in the United States and Europe were stunned in turn at the extreme nature of Russia's reaction, since NATO's goal—as defined by NATO — was to stop genocide., 28

From the Russian perspective the war in Kosovo was a projection of American imperialism aiming to establish a strategic presence in the region. The tension between the USA and Russia reached its highest level since the Cold War era. The situation became more complicated with the deployment of a small Russian contingent at the airport of Pristina, the capital of the Kosovo region. If the Russians had been able to fly in reinforcements, they could have secured part of Kosovo for the Serbs, thus destabilizing NATO's command. ${ }^{29}$ The crisis of 1999 appeared to be much more than a peacekeeping mission, since it involved the regional interests of the great powers, the United States and Russia.

Was European security threatened in the case of Kosovo? Simply put, it was, and this is true for several significant reasons.

First, NATO had to restore peace in the region and make sure that violence does not spread to other regions. Tension had been building up since 1989 in the predominantly

25 James M. Goldgeier and Michael McFaul, Power and Purpose: U.S. Policy Toward Russia after the Cold War (Washington, DC: The Brookings Institution, 2003), 247.

26

27 Goldgeier and McFaul, Power and Purpose, 247.

28 Ibid., 247.

29 Ibid., 266. 
Albanian inhabited Kosovo region. Diplomacy measures failed to stop the violence and NATO started an air-strike campaign to persuade Milosevic to end the violent outrage. According to NATO's official position on the conflict, the political objectives of the air campaign were to stop all military and repressive actions; to withdraw armed forces and position an international contingent; to guarantee the safe return of all refugees and to establish a political agreement complied with international law and the UN. ${ }^{30}$

Second, the Alliance had to operate without UN Security Council approval, which is a major violation of international laws and increased even further the diplomatic pressure on NATO. The United States and the United Nations attempted to stop the violence perpetrated against Kosovo Albanians by the Yugoslav government during the year before war. ${ }^{31}$ UN Security Council resolution 1160, adopted in March 1998, condemned the violence and put in place an arms embargo, while advocating the autonomy of Kosovo. ${ }^{32}$ After discussing the matter, the USA and Russia passed another resolution within the UN, the Security Council resolution 1199, "calling for a cease-fire and the withdrawal of Yugoslav security forces from the province, as well as access to Kosovo for nongovernmental and humanitarian organizations." 33 Despite all these precautionary actions violence continued and the crisis deepened. Russia supported the UN talks for a ceasefire and issuing resolutions, but it strongly opposed the use of force. Milošević did not comply with UN resolutions and NATO launched air strikes without the official agreement of all UN Security Council members as a result of Russia's veto. The intervention in Kosovo, without UN Security Council authorization and in violation of a state's sovereignty, was ambiguous for international diplomacy. ${ }^{34}$ This compromise could allow the USA to conduct more operations outside its Alliance territories in the future without Security Council approval. ${ }^{35}$ From a realist point of view, NATO's new tasks and purposes serve as a perfect cover for the pursuit of US national interests. As realism theory explains, powerful states strive to maximize their power and influence. The case of Kosovo allows the United States to increase its influence on the Balkans at the expense of Russia. An escalation in the region would also accelerate the eastward expansion of NATO, with the admission of Slovakia, Romania and Bulgaria to the Alliance, and increase the zone of stability. As a result, the Alliance would increase its military capabilities, territory and influence.

Third, the United States and its allies had to be very careful with Russia's interests in the region because, in a worst-case scenario, the crisis could have triggered an even larger conflict. Russia supported Yugoslavia and established and preserved its influence and interests in the region during the Cold War. The crisis in Kosovo strained US-Russian relations to a critical level for the first time since the crisis in Hungary and in

30 Goldgeier and McFaul, Power and Purpose, 249.

31 Ibid., 249-250.

32 Peter van Ham and Sergei Medvedev, Mapping European Security after Kosovo (Manchester: Manchester University Press, 2002), 93.

33 Goldgeier and McFaul, Power and Purpose, 249-250.

34 Ibid., 266.

35 Rynning, NATO Renewed, 87. 
Czechoslovakia in the Cold War period. Just over a year before the Kosovo war, NATO and Russia had signed the Founding Act for cooperation, but Russia's negative behavior could not be easily offset. The idea at the basis of the creation of such a partnership after the Bosnia War (1995) was to prevent cases of crisis like the one in Kosovo. ${ }^{36}$ This cooperation failed when it was put to the test of Kosovo war as a result of a conflict of interests. Although the crisis did not threaten vital security interests for preserving the national sovereignty of the two superpowers, the positions of Moscow and Washington confronted and all forms of cooperation between them faded. This is another example that shows that states cooperate with each other when they have a mutual benefit, but cooperation fails when there is a conflict of interests.

The conflict in Kosovo was the first real collision of interests between the Cold War adversaries. Russia was a long-time strategic ally of Yugoslavia and NATO's military intervention was not well received by Moscow. However, a major conflict between the two powers was avoided due to Russia's economic and military weakness and the policy of President Boris Yeltsin. ${ }^{37}$ The Kosovo crisis escalated the tension in the relations between the two countries, and the future expansion of NATO did not favor their improvement. In fact, the distance between the two major powers increased and Russian political elites remained opposed to NATO actions more than ten years later, as the case of Libya shows. ${ }^{38}$

The Kosovo war was an important case for NATO, since the organization had struggled to prove its transformed role after the end of the Cold War. With many specialists criticizing its continued existence, the Alliance needed to prove that it was capable of resolving security threats and conflicts elsewhere. The interests of the USA, along with the shared norms and values for the promotion of democracy, remain as a base for NATO's future actions and cooperation. In President Clinton's own words, "[w]hat NATO did here this weekend, was to reaffirm our commitment to a common future, rooted in common humanity." ${ }^{39}$ The explanation given for NATO's undertaking actions outside the UN Security Council mandate was the need to protect the western values on which NATO was founded. ${ }^{40}$

NATO is a key organization in tackling external threats, but in Moscow's view NATO's actions in Kosovo aimed to enhance the US influence on the Balkans. Clearly, Russia regarded the US-led NATO peacekeeping operation in Kosovo as an extension of the US sphere of influence to the Balkans - a region historically dominated by Russia. This argument was strongly supported by NATO's acquisition of three central European states less than two weeks before the conflict. ${ }^{41}$ Russian decision-makers considered

36 Goldgeier and McFaul, Power and Purpose, 248.

37 Oksana Antonenko, "Russia, NATO and European Security after Kosovo," Survival 41, no. 4 (Winter 1999-2000), 124-44.

38 Ibid.

39 USIS Washington File, Remarks by the President at the Close of the Washington Summit, EPF108, 26 April 1999.

40 Rynning, NATO Renewed, 86-87.

41 Goldgeier and McFaul, Power and Purpose, 249. 
NATO a political organization that aims its operations in accordance with the interests of the United States.

Russia's authority took a severe blow during the Kosovo crisis because its veto in the Security Council of the UN was ignored. ${ }^{42}$ That left Russian leaders with not many options but to offer diplomatic support to the military operation and to bring Milošević regime to an end. President Yeltsin did not take any measures to balance against NATO in Serbia, which showed the Russian leader's desire to maintain close relations with Washington, but also the significant decline of Russia's power and influence in the international arena. The actions of the US leaders in Kosovo and NATO's eastward expansion provided another nail in the coffin of US-Russian relations.

If NATO's intervention had been postponed or had not taken place and Russian interests had prevailed, the results for the Balkans would have been catastrophic. Ethnic violence would have spurred in other parts of the peninsula with disastrous consequences for European security. Failure to take action in the Kosovo crisis would have been deleterious for the region, for Europe as a continent and also for the USA and Russia. ${ }^{43}$ Therefore, NATO had to create and implement a successful plan in Kosovo that would restore peace and stability and would enhance the authority of the highly criticized institution.

NATO's intervention in Kosovo was successful and saved countless of innocent lives, but only because the Serbian regime was no match for NATO military capabilities and had no nuclear weapons. ${ }^{44}$ There were human rights violations in Chechnya and the Caucasus, too, but the USA and other major states could do little because of the nuclear power of Russia. "States take up human rights only if doing so does not contradict the pursuit of power," 45 and this is why many conflicts in the world remain unsolved and violence continues to emerge.

The war in Kosovo allowed the USA to broaden its influence in a region in which it faced serious opposition, and ultimately to establish its international influence. The renewed role of NATO in protecting western ideology and values is successful because the USA continues to claim benefit. ${ }^{46}$ The Alliance serves the interests of its most powerful member and for this reason preserves peace and development in conflict areas like Kosovo. Peace and stability in Kosovo would not have been achieved through diplomatic actions and sanctions alone:

\footnotetext{
Ibid., 249.

Ibid., 251.

44 Robert D. Kaplan, "Why John J. Mearsheimer is Right (About Some Things)," The Atlantic (January/February 2012), available at www.theatlantic.com/magazine/archive/2012/01/whyjohn-j-mearsheimer-is-right-about-some-things/308839 (13 May 2014).

46 Goldgeier and McFaul, Power and Purpose, 249.
} 45 Ibid. 
NATO prevailed in Kosovo because the United States invested heavily in the air campaign and because the fear of failure took hold of all allies who became convinced that Milošević's victory would spell NATO's demise. ${ }^{47}$

NATO's role in the post-Cold War era would indeed be considered irrelevant and unnecessary if it had failed to achieve victory in Yugoslavia. Neither the UN nor the OSCE were capable of handling an armed conflict as serious as the Kosovo crisis. The UN's lack of authority confirmed the realist theory that the international system represents anarchy and there is not a single legitimate institution that could prevent the occurrence of war.

European security was threatened even if some would argue that the conflict was merely regional and did not endanger the major European powers directly. It was NATO that restored security and promoted peace, despite the fact that the casualties and damage to infrastructure exceeded initial expectations. The successful military operation in Kosovo guaranteed the primacy of NATO in Europe's future. ${ }^{48}$

\section{NATO's Operation Unified Protector in Libya}

The case of Libya as part of the Arab Spring created serious issues for European Security. The proximity of the North African state to Europe faced NATO decision makers with the possibility of another "out of borders" mission. The inhumane actions taken against the democratic ambitions of the people of Libya during colonel Muammar alQaddafi's dictatorship as well as the flow of refugees towards southern Europe left NATO with no choice but to intervene in order to put an end to the oppressive regime.

When the Arab Spring events reached Libya in 2011, the oppressed population hoped for non-violent protests that would follow the successful democratic processes in Tunisia and Egypt. But instead of resigning, as Zine el-Abidine Ben Ali and Hosni Mubarak had done, Qaddafi started violent clashes with the protesters, resulting in civil war. ${ }^{49}$ The international community responded to the aggression by imposing an arms embargo, freezing Libyan assets, suspending the country from the Arab League and imposing a no-fly zone. The escalation of violence led to UN Security Council resolution 1973, authorizing military intervention. ${ }^{50}$

Was European Security threatened during the Libyan case and in what way? European Security was threatened, and this was due to several important reasons.

First of all, the major human rights violations and the killings of protesters on Qaddafi's orders provoked the UN Security Council to take actions. The regime of Qaddafi was accused of "gross and systematic violation of human rights, including arbitrary detentions, enforced disappearances, torture and summary executions." ${ }^{, 51}$ NATO took

47 Rynning, NATO Renewed: The Power and Purpose of Transatlantic Cooperation, 76.

48 Peter W. Rodman, "The Fallout from Kosovo," Foreign Affairs 78, no. 4 (1999), 45-51.

49 Ivo H. Dadlder and James G. Stavridis, "NATO's Victory in Libya," Foreign Affairs 91, no. 2 (2012), 2-7.

50 Dadlder and Stavridis, "NATO's Victory in Libya."

51 United Nations Security Council Resolution 1973 (2011). 
the UN mandate very seriously and conducted Operation Unified Protector, supplying arms to the rebels and establishing total control over the country by sea and air. The Alliance's military actions were aimed at protecting areas populated by civilians. During the entire operation, NATO held consultations with the UN and the Arab League to maximize efficiency. ${ }^{52}$ The operation proved very efficient and could serve as a model for future military interventions. Although the events in Libya did not threaten the security of Europe directly, Europeans could not allow a conflict to emerge in their own backyard as it had in the Balkans. Failure to act on the part of NATO and, more importantly, its European members would have undermined their ability to respond to security threats and hence the authority and purpose of the Alliance itself. The emerging crisis needed a swift response from the international community, which NATO provided with exceptional accuracy. NATO succeeded in protecting those civilians and, ultimately, in providing the time necessary for local forces to foster their freedom from Muammar alQaddafi. ${ }^{53}$ As Secretary General Anders Fogh Rasmussen remarked, "we created the conditions for the people of Libya to determine their own future." 54 The successful results of the operation were even more important because of the cooperation and tasksharing actions between NATO members - proof that NATO's new role was justified.

Second, Libya's location is not far from Southern Europe where major NATO members such as Italy, Greece and France were worried about the enormous flow of refugees that swept through Southern Europe, especially Italy and France. Refugees fled from Libya to the Italian island of Lampedusa and to Malta, the closest European shore and a passage to other nearby destinations. The problem of refugees became even more serious when their number increased. Although most of them were well-educated and qualified to work, they were issued only temporary residence permits and were not allowed to work or stay. The European states already faced a difficult situation with increasing unemployment and social unease towards emigrants. The conflict in Libya created extra problems for the countries of Southern Europe. Italy requested help from the EU to relocate and provide support for the refugees. However, the European states did not reach a consensus on the matter and every concerned state had to deal with the issue on its own. Another serious problem this situation posed for European security was organized crime, which was taking advantage of the growing number of people willing to leave Libya in search for better living conditions. From a financial perspective, this was a heavy burden for the strained European economies.

Third, a conflict in Europe's immediate neighborhood means that European security was threatened, at least indirectly, since the interests of European states were affected. Libya is rich in oil and is the third largest exporter of oil to European states. With Norway and Russia as the current dominant suppliers and since the latter was not regarded as reliable partner on the grounds of its attempts at energy monopoly, Libya was re-

52 NATO's Official Statement on Libya, March 2011.

53 Dadlder and Stavridis, "NATO's Victory in Libya."

54 Press conference by NATO Secretary General on the latest developments in Libya and Operation Unified Protector, 21 October 2011. 
garded as exceptionally important for European energy security. ${ }^{55}$ When the conflict escalated into a civil war, European states had another very good reason to interfere and protect their interests in the energy sphere. Libyan energy resources cover 17 percent of Europe's needs, but as the EU has yet to establish a common energy policy, trade relationships with Libyan exporters must be determined on an individual basis. ${ }^{56}$ The EU Commission stated that "following the demise of the Qaddafi's regime the EU will facilitate Libya's full integration in regional and EU-Mediterranean energy cooperation structures. ${ }^{.57}$ In other words, the EU wanted to increase its influence in Libya and assist its oil companies to receive an even larger share of Libyan oil output. With Great Britain and France taking the leading role of the operation, and Italy providing military bases, airships and naval forces, it was obvious that the most concerned states were the ones investing heavily in the operation. The economic consequences of a sudden outflow of Libyan oil would be dire, especially for the powerful countries that depend on it. The EU member states were also looking for a way around their dependence on Russian energy supplies, and the geostrategic proximity of Libya was appropriate for such diversification policy. ${ }^{58}$

The United States took a different course in this conflict, allowing the European members of NATO to prove their ability to conduct a military intervention without US support. NATO successfully coordinated the actions of 18 countries and 4 partner states under a unified command. Despite not taking the leading role in the operation, the USA provided crucial intelligence, targeting capabilities and support to its allies. ${ }^{59}$ Washington did not miss the opportunity to increase its international influence with the intervention in Libya, but it was too preoccupied with its own wars fought in the Middle East. Ellen Hallams and Benjamin Schreer noted in a recent article that "while the US will certainly maintain an interest in NATO as an instrument of its foreign and security policy, its willingness to lead it in operations of lesser national interest will diminish." Domestic demand for military budget cuts also played a role in the decision of NATO's largest member. American politicians had long criticized their European counterparts' lack of defense spending, and with pressure on its own budget another US-led operation would be unsustainable. ${ }^{61}$ American leaders prioritized foreign policy in order to maximize efficiency in conflicts they regard as vital for national interest. Despite the non-US leadership, the intervention in Libya was very successful from an economic point of view with only several billions of dollars spent - a fraction of what was spent on the

55 Namiq Abbasov, "Energy potential of Libya: How is it essential for the European Energy Security?" Caspian Weekly, 2-3 October 2011.

Ibid., 2-3.

57 Ibid., 2-3.

58 Ibid., 2-3.

59 Dadlder and Stavridis, "NATO's Victory in Libya."

${ }^{60}$ Ellen Hallams and Benjamin Schreer, "Towards a 'post-American' alliance? NATO burdensharing after Libya," International Affairs 88, no. 2 (2012), 313-327.

61 Ibid. 
interventions in the Balkans, Afghanistan and Iraq. ${ }^{62}$ The air-strike campaign was a success that showed the future of NATO cooperation and task-sharing operations with increased efficiency.

One could argue that, in the case of Libya, NATO was used as a tool for proclaiming the foreign and security interests of its major European members and, therefore, for increasing western influence. The states that played the biggest role in the intervention were the ones that had the biggest benefit from its successful outcome. In the intervention in Libya, US interests were not essentially concerned. The strategic resources of Libya are far more important to NATO's major European members than to the USA. The region is substantial for European energy security and American decision-makers acknowledge this fact. With France and the United Kingdom responsible for more than a third of the amount of used force, and Italy providing a large number of bases and aircrafts, it is clear that the countries that are most dependent on Libyan oil were also the most active in the resolution of the conflict. ${ }^{63}$ The Arab Spring gave western states the opportunity to increase their influence and establish firm control of the region.

Consequently, the assumption that states act according to their national interests is confirmed. With many conflicts in the world left unresolved, alliances and coalitions created for humanitarian intervention and peacekeeping show that they are simply interest-related. The state's self-interested and individualistic behavior often exploit humanitarian intervention to gain benefit. If the operation in Libya was intended to achieve peaceful ceasefire and a change of regime, why was it carried out with military means, and why did power politics still dominate international relations?

European states had to protect their interests in Libya because they are dependent on its oil exports. The United States felt that its interests were not sufficiently concerned and took a supporting role in the intervention. Russia was against the military operation and called for a diplomatic resolution of the conflict. With Moscow's overwhelming presence in the European energy market, one would have expected another veto in the Security Council of the UN. However, Moscow did not use its veto power because its national interest was remotely concerned and its oil and natural gas deliveries would continue to supply Europe.

Soon after the success of NATO against Qaddafi, the clashes between government forces and protesters in Syria have been far more serious from a humanitarian point of view. The raging conflict is one of the most violent in recent memory, with more than 100,000 people killed, at least half a million wounded, millions of people displaced and tens of thousands detained. ${ }^{64}$

Despite the disaster in Syria, Russia and China vetoed against a UN resolution and military intervention. Atrocities and massacres seem to fade from the limelight and pave the way to national interests. For both Moscow and Beijing it was of the utmost impor-

62 Dadlder and Stavridis, "NATO's Victory in Libya."

63 Hallams and Schreer, "Towards a 'post-American' alliance?"

64 International Committee of the Red Cross (ICRC) and Syrian Arab Red Crescent (SARC) newsletter, March 2014. 
tance to prevent the USA from spreading its influence in this strategic region through NATO and to prevent the western Alliance from setting foot in their neighborhood. Whilst in Libya the interests of Russia and China were not crucially concerned, in Syria they were. As a result of geographical proximity, most of the oil exports from Syria and Iran go to Russia and China. Syria's powerful ally Iran has been a long-time target for the USA and recent events have increased tension between the two countries. The current events in eastern Ukraine clearly demonstrate the confrontation between NATO's and Russia's strategic interests.

These two examples show that power politics is still relevant in the post-Cold War era. The overall trend in the behavior of superpowers has not changed, and this appears clearly from a comparison of the cases of Kosovo and Libya.

\section{Comparison of the Cases of Kosovo and Libya}

The cases of Kosovo and Libya have much in common. Their similarities could be summarized in the following way. First, both conflicts were characterized by serious atrocities and disregard for human rights. In Kosovo the ethnic cleansing of the Albanian population almost ignited a disastrous conflict in Europe. Thousands of civilians were killed or threatened. In Libya the clashes between the forces of self-proclaimed head of state colonel Qaddafi and protesters against his dictatorship escalated into a civil war. NATO operations, although not perfect, saved countless lives from certain death in both events. European security was threatened in both cases. Due to its location in a region with ethnic tension, the conflict in Kosovo could have spurred further clashes between other states and thus create havoc on the European continent. In Libya the European security was threatened in a slightly different way - not by a direct armed conflict on the continent, but by economic and strategic issues. The immense outflow of refugees in both cases created serious problems for the European governments. In both cases, NATO was the only institution that was capable of restoring peace and security swiftly and efficiently. Despite being criticized for its seemingly pointless existence in the postCold War era, the Alliance showed that it is not only capable and powerful, but also an effective protector of western security and interests.

Second, both Yugoslavia and Libya were under a dictatorship, that of Slobodan Milošević and Muammar Al-Qaddafi, respectively. The Yugoslav leader took decisions that led his country to war with NATO and was condemned by the international community. His actions led to a loss of thousands of lives, an arms embargo, serious economic and infrastructural damages, deeper ethnic divide and tension. Similarly, Colonel Qaddafi's authorization of the use of military force against all those who opposed him was an inhumane and disastrous judgment. He threatened to cleanse his country "house by house" from all the "rats" that were protesting against his rule following the Arab Spring events in North Africa ${ }^{65}$ In both cases NATO's actions proceeded in a similar fashion: arms embargo, no-fly zone, economic and diplomatic sanctions and ultimatum for ceasefire. Air strikes started soon thereafter, and NATO restored Euro-

65 Dadlder and Stavridis, "NATO's Victory in Libya." 
pean security and prevented further genocide. The similarities here are connected with the form of governance. The new threats for NATO in the post-Cold War era are mostly related to terrorism, regional and ethnic conflicts and weapons of mass destruction. ${ }^{66}$ The cases of Kosovo and Libya share a form of autocratic governance using its authority and power to oppress the population. NATO responded in the same positive way towards the atrocities and human rights violations in both cases and carried out successful operations. The intervention in former Yugoslavia was considerably more expensive and caused more infrastructural damage for Serbia and the Kosovo region. In Libya the results of Operation Unified Protector exceeded expectations, achieving a successful democratic transition with low operational costs and minimum damage. This shows how much the organization improved its security capabilities and efficiency.

Third, the strategic interests of the USA, Russia, and major European states, except Germany, were involved in both conflicts. It was a turning point for NATO, because the organization had struggled to find its new purpose in the post-Cold War period. With many criticizing the continued existence of the Alliance on the grounds of a lack of a real threat, NATO had to prove that it was still important and capable of protecting European security. NATO's failure to intervene in the Kosovo crisis would have meant the end of NATO as a collective organization. The United States also had a serious strategic interest in maintaining NATO as an active and responsible organization. In Kosovo, the USA was investing heavily because of the opportunity to establish its international influence in a traditionally pro-Russian region. In many ways, the conflicts of interests between Washington and Moscow are reminiscent of behavioral patterns from the Cold War era. In Libya it was not the USA but the European major powers that invested the most in military operations, since their own interests were concerned. The oil supplies of Libya presented an excellent opportunity for the EU to diversify its energy supplies and decrease its dependence on Russia. Libyan oil and natural gas allowed European countries to consolidate their energy security, whilst also accelerating Libya's development. $^{67}$

Both cases confirm that international organizations are guided by the self-interest of its members. States continue to compete for power and influence and use every opportunity to increase their dominance in the international arena. In Kosovo the USA wanted to achieve a strategic position and expand its influence in the Balkans to the detriment of Russia. As a result of the hegemony of the United States, NATO is used as a military tool that serves the interests of its most powerful member. In Libya the US only supported its allies because of immense domestic pressure for military budget cuts and because Washington's interests in Tripoli were not of vital importance and did not require heavy investment. In Libya, however, the interests of the major European states, except Germany, were affected. They widened their sphere of influence by establishing advantageous trade relations for importing strategic resources. Using military power to

66 NATO 2020: Assured Security; Dynamic Engagement, NATO Official Texts, 17 May 2010.

67 Namiq Abbasov, "Energy potential of Libya: How is it essential for the European Energy Security?" Caspian Weekly, 1 October 2011. 
resolve the conflict in Libya, the EU sought to establish new profitable relations with an oil-rich country.

A fourth similarity that further confirms the realism theory's assertions concerns Russia's position against NATO's military operations. In the case of Kosovo, Moscow voted against the use of force to resolve the conflict in the UN Security Council, calling for more diplomatic pressure on Milošević instead. If NATO had refrained from intervening to stop the massacres because of the Russian veto, Milošević would have had the time and opportunity to gain advantage and continue the pursuit of his dictatorship goals. The decision to start air strikes against Belgrade, made by the President Clinton's administration, prevented further casualties in Kosovo but strained US-Russia relations to an extent reminiscent of the Cold War. Russia's position was almost identical in the Libya conflict, but it refrained from vetoing the UN resolution authorizing NATO's intervention. Russia was against an intervention, knowing that the resulting benefits for the EU states would jeopardize its monopolistic position in the energy market in Europe. The events in the North African state shared the tone of the Kosovo case with regard to the disharmony and lack of unanimity within the UN Security Council, with ten states voting for resolution and five absenting. ${ }^{68}$ The foreign policy actions of Russia were similar to the ones taken in Kosovo, calling for immediate ceasefire and more active diplomatic actions in order to prevent human losses. Moscow criticized the UN resolution for not being in line with the practice of the Security Council and for not answering important questions such as how it would prevent a destabilization of the region after the operation. ${ }^{69}$ Russia also argued for a different, peaceful resolution of the crisis but did not receive the support of its partners, who were more interested in measures of force. ${ }^{70}$ Russia's protection of its national interests through its veto power and diplomatic pressure in the UN Security Council confirms the realism theory according to which states continue to compete for power in the international arena. Human rights violations and the suffering of civilians are still reported every day, and the UN has done nothing to prevent them. Superpower confrontation has hindered many humanitarian operations, for example in Chechnya, the North Caucasus and Tibet. ${ }^{71}$

The eastward expansion of NATO has further strained its relations with Russia and has undermined the importance of the military power of the major states. In Russia's national security concept, President Putin outlined the importance of military power in international relations:

The formation of international relations is accompanied by competition and also by the aspiration of a number of states to strengthen their influence on global politics, includ-

68 Timothy Bancroft-Hinchey, "Libya: The position of the Russian Federation," Pravda, 18 March 2011, 1.

69 Ibid.

70 Ibid.

${ }^{71}$ Huseyn Aliev, "Neo-Realism and Humanitarian Action: From Cold War to Our Days," The Journal of Humanitarian Assistance (May 2011), 6, available at http://sites.tufts.edu/jha/archives/1173 (13 May 2014). 
ing by creating weapons of mass destruction. Military force and violence remain substantial aspects of international relations. ${ }^{72}$

Russia continues to see NATO's actions as a threat to its national interests. The intervention in Kosovo was regarded as the expansion of US influence and dominance through NATO. In that particular case, NATO's proposed intervention did not receive the authorization of the UN Security Council due to Russia's veto, but this did not prevent NATO from intervening anyway. This episode shows that the legitimacy of the UN as a leading peace institution was undermined. With an intervention conducted without the authorization of the UN, how could the international community guarantee the absence of military interventions and conflicts in the future? Even an organization as vast as the UN could not unify the positions of its powerful Security Council members. Once more, institutions showed their significant dependence on states and their behavior. After the events in Kosovo, the UN suffered a major blow to its authority, and NATO strengthened its aspiration to a role of a global security organization. ${ }^{73}$

Twelve years after the Kosovo crisis, Moscow could do little to prevent NATO's operation against Qaddafi's regime. For the transatlantic allies, Russian influence and interests in the western part of the Mediterranean are not as strongly represented as in other regions of the world. Therefore, the EU states were right in thinking that Russians should not interfere in business that is strictly European. That is not the case in the conflict in Syria, where Russian and Chinese interests are seriously concerned in view of a future military operation. The previously mentioned example of the situation in Syria validates the claim that the states' self-interested behavior will continue to dominate the world order. States will continue their quest for power and will not cease to pursue their nationalistic goals by balancing power against each other.

Fifth, the operations in Kosovo and Libya were conducted outside the borders of NATO members. Since its creation, the organization's original purpose was to act as a defense alliance against any type of aggression from a non-member state, presumably from the Soviet Union. However, NATO significantly changed after the end of the Cold War. It adopted a new role in tackling new security threats and could therefore operate outside its borders if European security is threatened. In Kosovo, NATO decision-makers reckoned that the Alliance must respond to a humanitarian crisis even if there was no direct attack on one of its members. NATO needed to show its determination to resolve the crisis and to demonstrate its leading role for the future of European security. In Libya and Afghanistan, NATO extended its military actions even beyond the borders of its member states.

NATO's expansion and acquisition of new members means not only increased capability, but also more responsibility. With its dialogue for cooperation and partnership in the Mediterranean, Ukraine and Georgia, NATO reaches further for international influence, power and the spreading of democratic principles. The Alliance's operational

72 "Russia's National Security Concept," Arms Control Today (January/February 2000), www.armscontrol.org/act/2000_01-02/docjf00 (12 April 2014).

73 Van Ham and Medvedev, Mapping European Security after Kosovo, 98. 
scope is now no longer limited to the transatlantic region, but has spread throughout the Mediterranean and the Middle East. The actions in Kosovo and Libya show the enlarged role of the Alliance. In the light of the aforementioned considerations, this could be interpreted as a further step towards the growth of NATO into a global security organization led by the hegemonic ambitions of the USA and its allies. Only the future will tell how far this will go and how powerful the organization will become.

The comparison of the two cases reveals numerous similarities and shows that the behavior of states remains essential for international relations and security. Twelve years elapsed between the two conflicts. During that period, the efficiency of NATO operations clearly increased. Success in Libya was achieved at a lower cost, with less infrastructural damage and collateral casualties than in the Kosovo scenario. In both cases, humanitarian disaster was prevented and innocent lives were saved. Further threats from the ethnic violence in Kosovo and from the atrocities in Libya, along with refugee problems and economic issues were avoided thanks to the success of the intervention.

The cases of Kosovo and Libya have much in common and present an interesting comparison. Ethnic violence in Kosovo and oppressions in Libya show that state-to-state conflicts are less likely to occur in the post-Cold War period. Nonetheless, the international reaction was very similar despite the lapse of time between the conflicts. Disagreements within the UN Security Council continue because states persevere in the pursuit of their egoistic interests. When diplomacy fails, military force comes in, or, to paraphrase Clausewitz, war is the continuation of diplomacy by other means. NATO has been severely criticized by theorists for struggling to find its new purpose.

\section{Conclusion}

Great powers, grand strategy, and national competition continue as the United States dominates, but the other powers - including Russia, China, and Europe and regional powers- contend for influence. ${ }^{74}$

NATO provides stability and security across Europe but it is no secret that the Alliance is a military organization. No other institution, including the OSCE, the EU and the UN, could perform this task better and with higher efficiency. For more than sixty years, the continent that was once plagued by violent state-to-state conflicts, has not experienced a major war thanks to NATO's presence and actions. The Americans and Europeans share a common vision of security matters, and the hegemonic leadership of the USA has played an essential role in maintaining European security. The comparison of the two cases has also shown the enhanced weight of the member states and the European countries' active role in protecting their regional interests and values. NATO has significantly contributed to the increased cooperation and efficiency of its members.

As the cases of Kosovo and Libya show, NATO has proved that it protects western ideology and values as well as the interests of its most powerful members in a world

74 John J. Mearsheimer, "Realism, the Real World, and the Academy, " in Michael Brecher and Frank P. Harvey, eds., Realism and Institutionalism in International Studies (Ann Arbor, MI: The University of Michigan Press, 2002), 23-33. 
dominated by state competition and pursuit of national interests. It could be concluded that the Alliance survived in the aftermath of the Cold War not only because it assimilated new goals and strived to achieve them, but also because it was in the best interest of the USA. Relations between the USA and the European states are very important for the interests of Washington. America's leadership of NATO gained influence and power with NATO's intervention in Kosovo. In Libya it was the European allies that gained profit and protected their interests with the help of NATO.

The two cases examined showed how the interests of the USA and Russia played a role affected in NATO's operations. Russia's position was similar in both conflicts, as it opposed the use of force for the resolution of the crisis. The United States' course of action was slightly different in the two cases, but overall it aimed at increasing its geopolitical influence.

This analysis of the behavioral patterns of the former Cold War adversaries could provide a useful interpretation and perhaps an explanation of the current events in Ukraine. The confrontation between the USA and Russia is far from over. The continued expansion of NATO and, hence, American geopolitical influence has predictably angered Moscow's officials and has directly concerned their essential security interests. The promise of the Bush administration in 2008 that Georgia and Ukraine would eventually be admitted to join NATO forced President Vladimir Putin to state clearly that this is a line the US should not cross. ${ }^{75}$ As John J. Mearsheimer wrote in a recent article, "Georgia and Ukraine are not just states in Russia's neighborhood; they are on its doorstep." Major powers, especially Russia, are very sensitive to possible threats near their borders and sometimes they act ruthlessly to counter potential dangers. ${ }^{77}$

As in the case of the never-ending bloodshed in Syria, the escalating tension in eastern Ukraine and the annexation of the Crimean peninsula, the international community and the UN seem once again stranded and powerless, unable to find a solution and to prevent killings and with few options to counter Russia's moves. When vital interests are at stake, states inevitably try to ensure their safety at all costs, international law and human rights giving way to the more powerful solutions of decision-makers.

The pursuit of power and state interests continues to dominate the global political arena, as countries do not cease to look for opportunities to increase their influence on others in order to ensure their own safety and prosperity, and we may well see more military interventions in the future.

75 Stanley R. Sloan, "Differing Perspectives on Ukraine, Russia, NATO and US Policy," War on the Rocks, March 2014, http://warontherocks.com/2014/03/differing-perspectives-on-ukrainerussia-nato-and-us-policy (18 April 2014).

76 John J. Mearsheimer, "Getting Ukraine Wrong," The New York Times, March 2014, www.nytimes.com/2014/03/14/opinion/getting-ukraine-wrong.html?_r=0 (18 April 2014).

77 Ibid. 


\section{Bibliography}

"Russia's National Security Concept." Arms Control Today (2000).

Abbasov, Namiq. "Energy potential of Libya: How is it essential for the European Energy Security?" Caspian Weekly (2011).

Aliev, Huseyn. "Neo-Realism and Humanitarian Action: From Cold War to Our Days." The Journal of Humanitarian Assistance (2011): 6.

Antonenko, Oksana. "Russia, NATO and European Security after Kosovo." Survival 41, no. 4 (2000): 124-44.

Bancroft-Hinchey, Timothy. "Libya: The position of the Russian Federation." Pravda (2011): 1 .

Dadlder, Ivo H., and James G. Stavridis. "NATO's Victory in Libya." Foreign Affairs 91, no. 2 (2012): 2-7.

Gheciu, Alexandra. NATO in the New Europe: The Politics of International Socialization after the Cold War. Redwood City, CA: Stanford University Press, 2005.

Goldgeier, James M., and Michael McFaul. Power and Purpose: U.S. Policy Toward Russia after the Cold War. Washington, DC: The Brookings Institution, 2003.

Hallams, Ellen, and Benjamin Schreer. "Towards a 'post-American' alliance? NATO burden-sharing after Libya." International Affairs 88, no. 2 (2012): 313-327.

Historical Overview NATO's role in relation to the conflict in Kosovo. NATO official statement, 1999.

J. Barkin, Samuel. International Organization: Theories and Institutions. New York: Palgrave Macmillan, 2005.

Kaplan, Robert D.. "Why John J. Mearsheimer is Right." The Atlantic (2012).

Kay, Sean. Global Security in the Twenty-First Century: The Quest for Power and the Search for Peace. Peace United Kingdom: Rowman \& Littlefield, 2012.

Mearsheimer, John J.. "Getting Ukraine Wrong." The New York Times (2014).

Mearsheimer, John J.. "Realism, the Real World, and the Academy." In Realism and Institutionalism in International Studies, 23-33. Vol. 23-33. Ann Arbor: The University of Michigan Press, 2002.

Mearsheimer, John J.. Realism, the Real World, and the Academy, in Millennial Reflections on International Studies. Ann Arbor, MI: The University of Michigan Press, 2002. 
THE QUARTERLY JOURNAL

NATO 2020: Assured Security; Dynamic Engagement - Analysis and Recommendations., 2010.

NATO official report on Libya., 2011.

NATO's Official Statement on Libya., 2011.

Provisional Assessment of Civilian Casualties and Destruction in the Territory of the FRY from 24 March to 8 June 1999. Ministry of Foreign Affairs, Yugoslavia, 1999.

Remarks by the President at the Close of the Washington Summit. USIS Washington File, 1999.

Resolution 1199. UN Security Council, 1998.

Resolution 1203. UN Security Council, 1998.

Rodman, Peter W.. "The Fallout from Kosovo." Foreign Affairs 78, no. 4 (1999): 45-51.

Rogers, Paul. The Casualties of War: Libya and Beyond. Oxford Research Group, 2011.

Rynning, Sten. NATO Renewed: The Power and Purpose of Transatlantic Cooperation. New York: Palgrave Macmillan, 2005.

Shah, Anup. "Crisis in Libya." Global Issues (2011): 2.

Sloan, Stanley R.. "Differing Perspectives on Ukraine, Russia, NATO and US Policy." War on the Rocks (2014).

United Nations Security Council Resolution 1973., 2011.

US State Department Report., 1999.

Van Ham, Peter, and Sergei Medvedev. Mapping European Security after Kosovo. Manchester: Manchester University Press, 2002.

Waltz, Kenneth N.. "Structural Realism after the Cold War." International Security 25 (2000): 37 . 